\title{
Pseudomonas prosekii isolated in Antarctica inhibits plant- pathogenic strains of Pseudomonas viridiflava and Pseudomonas fluorescens
}

\author{
Kateřina Snopková ${ }^{1,2}$, Kristýna Dufková $^{1}$, David Šmajs ${ }^{1 *}$ \\ ${ }^{1}$ Department of Biology, Faculty of Medicine, Masaryk University, Kamenice 753/5, \\ 625 00, Brno, Czech Republic \\ ${ }^{2}$ Institute for Microbiology, Faculty of Medicine, Masaryk University and St. Anne's \\ University Hospital Brno, Pekařská 664/53, 65691 Brno, Czech Republic
}

\begin{abstract}
Pseudomonas-caused plant diseases are present worldwide and affect most of the major lineages of higher plants which, as a consequence, may result in significant economic losses. Despite the use of bacteriocins produced by rhizosphere and soil bacteria has been nowadays considered as novel crop protection approach, antagonistic interactions of cold-adapted isolates toward agriculturally important phytopathogenic bacteria have not been studied yet. In this study, we tested inhibition activity of Antarctic Pseudomonas spp. against phytopathogenic pseudomonads. Four Antarctic stains (P. prosekii CCM 8878, CCM 8879, and CCM 8881 and Pseudomonas sp. CCM 8880) inhibited several phytopathogenic strains of $P$. viridiflava and $P$. fluorescens. Based on inhibition zone character and previous genome research we suggest that L-pyocin activity was responsible for this effect against $P$. viridiflava strains and that tailocin inhibited $P$. fluorescens isolate.
\end{abstract}

Key words: pyocin, Pseudomonas, phytopathogen, tailocin, antimicrobial agents, James Ross Island

DOI: $10.5817 / \mathrm{CPR} 2021-2-18$

\section{Introduction}

Pseudomonas is an ubiquitous bacterial genus with wide metabolic plasticity resulting in colonization of various abiotic and biotic environments. A considerable number of species could inhabit terrestrial and aquatic environments, even the extreme ones, or could be associated with

plants, invertebrate or human hosts (Palleroni 2015). The phytopathogenic Pseudomonas spp. cause plants diseases ranging from necrotic lesions and spots of stems, leaves or fruits to tissue macerations causing rots, blights, cankers, hyperplasias (i.e., production of galls or scabs), and vascular

Received November 8, 2021, accepted January 24, 2022.

*Corresponding author: D. Šmajs <dsmajs@med.muni.cz>

Acknowledgements: The authors thank to the Collection of Phytopathogenic Bacteria, Prague, Czech Republic for providing the phytopathogenic strains. Further, we thank to the scientific infrastructure of the J. G. Mendel Czech Antarctic Station (supported by the MEYS CR, Project LM2015078 CzechPolar2). 
infections resulting in wilts. Pseudomonascaused plant diseases are worldwide spread and affect most of the major lineages of higher plants (Smith et al. 2009), having large economic impact. On the other hand, several Pseudomonas strains could be used as agricultural inoculants for plant growth promotion, defense priming and protection against other pathogens ( $\mathrm{Hu}$ et al. 2021, Flury et al. 2016, Loper et al. 2012). For example, plant growth promoting strain $P$. syringae $\mathrm{pv}$. syringae $260-02$ controls colonization by plant pathogenic $P$. syringae pv. tomato DC3000, fungus Botrytis cinerea or Cymbidium Ringspot Virus (Passera et al. 2019). In competition interactions, pseudomonads produce various secondary metabolites, such as narrow spectra proteinaceous toxins called bacteriocins (Majeed et al. 2011, Oluyombo et al. 2019).

Bacteriocins produced by Pseudomonas spp. are referred as pyocins (Michel-Briand and Baysse 2002). Pyocin group varies in size, cytotoxic activity, immunity mechanisms, and killing spectrum (Ghequire and De Mot 2014). Soluble pyocins encompass colicin-like, microcin-like and L-type pyocins which are characterized by low molecular weight. Colicin-like pyocins (S-type and M-type) exhibit modular organization containing domains responsible for recep-

\section{Material and Methods}

\section{Bacterial strains and cultivation conditions}

Pseudomonas spp. strains used throughout this study were collected from the northern part of the James Ross Island, Antarctica, belonging to the North-east Antarctic Peninsula region (according to classification by Terauds and Lee (2016). Soil and vegetable dwelling strains were obtained from to the vicinity of the Johann Gregor Mendel Station (63 $48^{\prime} 02^{\prime \prime} \mathrm{S}, 57^{\circ}$ $52^{\prime} 57^{\prime \prime} \mathrm{W}$ ) during the austral summer season of years 2007-9. All strains were maintained in the Czech Collection of Micro- tor-binding, translocation, and killing by nuclease or pore forming activity (Barreteau et al. 2012, Michel-Briand and Baysse 2002). Microcin inhibiting DNA gyrase has been identified in several Pseudomonas spp. (Metelev et al. 2013). L-type pyocins harbor tandem lectin domains targeting the cell envelope (Ghequire et al. 2018, McCaughey et al. 2014). Tailocins, high-molecular-weight (HMW) pyocins, are represented by myophage (R-type) and siphophage (F-type) tail-like structures (Nakayama et al. 2000) and their bactericidal activity is caused by the depolarization of the cytoplasmatic membrane (MichelBriand and Baysse 2002). Pyocin production has been reported for diverse pseudomonads, in silico analyses revealed widespread occurrence of pyocin genes across various Pseudomonas spp. (Ghequire and De Mot 2014, Loper et al. 2012).

Our previous research confirmed production of both tailocins and soluble pyocins by Pseudomonas spp. collected in James Ross Island, Antarctica (Snopková et al. 2018, 2021). The aim of the present study was to assess a pyocin-based inhibition effect of Antarctic Pseudomonas spp. against agricultural important plant-pathogenic Pseudomonas spp.

organisms (Brno, Czech Republic). The strains were subjected to direct cross inhibitory assay, the result of which was published recently by Snopková et al. (2021) together with detailed strain characteristics.

Phytopathogens causing severe disease of agriculturally important plants (Pseudomonas viridiflava, P. putida, P. fulva, $P$. marginalis, $P$. fluorescens, $P$. tolaasii) were provided by the Collection of Phytopathogenic Bacteria (Prague, Czech Republic). The isolates were causative or suspi- 
cious agents of plant diseases, several isolates were epiphytic and saprophytic bacteria connected to other phytopathogens or exhibited ice nucleation activity. The strains were isolated mainly from vegetable plants (potato, parsley, clover, cabbage, and apricot) or grape wine, less frequently from Amaryllis sp. or trees (horsech- estnut, ornamental tree) in the Czech Republic or the Netherlands. Further information about phytopathogenic strains are listed in Table 1.

Bacteria were grown in a Tryptone Yeast (TY) agar (8 g/l casein, $5 \mathrm{~g} / \mathrm{l}$ yeast extract, $5 \mathrm{~g} / \mathrm{l}$ sodium chloride, $\mathrm{pH} 7.5$; HiMedia, Mumbai, India) at $25^{\circ} \mathrm{C}$ or $30^{\circ} \mathrm{C}$.

\begin{tabular}{|c|c|c|c|c|}
\hline Species & Strain & Source & Pathogenicity & Year $_{\text {iso }}$ \\
\hline P. viridiflava & VURV-B 025 & horsechestnut, NL & virulent strain & 2010 \\
\hline P. putida & VURV-B 051 & potato, $\mathrm{CZ}$ & blight brown lesion on stem & 2010 \\
\hline P. putida & VURV-B 052 & potato, $\mathrm{CZ}$ & bacterial soft rot disease & 2010 \\
\hline P. viridiflava & VURV-B 069 & parsley, CZ & CA of soft rot disease & 2011 \\
\hline P. viridiflava & VURV-B 070 & parsley, CZ & CA of soft rot disease & 2011 \\
\hline P. viridiflava & VURV-B 071 & parsley, CZ & CA of soft rot disease & 2011 \\
\hline P. putida & VURV-B 073 & parsley, CZ & CA of soft rot disease & 2011 \\
\hline P. putida & VURV-B 074 & parsley, CZ & CA of soft rot disease & 2011 \\
\hline P. putida & VURV-B 088 & potato, $\mathrm{CZ}$ & CA of soft rot disease & 2011 \\
\hline P. putida & VURV-B 099 & parsley, CZ & soft rot symptoms & 2012 \\
\hline P. viridiflava & VURV-B 102 & clover, $\mathrm{CZ}$ & soft rot symptoms & 2013 \\
\hline P. fulva & VURV-B 150 & ornamental tree, $\mathrm{CZ}$ & epiphytic bacteria & 2006 \\
\hline P. marginalis & VURV-B 161 & cabbage, $\mathrm{CZ}$ & epiphytic bacteria & 2006 \\
\hline P. fluorescens & VURV-B 168 & grape wine, $\mathrm{CZ}$ & $\begin{array}{l}\text { epiphytic bacteria, } \\
\text { opportunistic pathogen }\end{array}$ & 2006 \\
\hline P. viridiflava & VURV-B 169 & grape wine, $\mathrm{CZ}$ & $\begin{array}{l}\text { saprophyt accompanying } \\
\text { CA of crown gall }\end{array}$ & 2006 \\
\hline P. fluorescens & VURV-B 171 & grape wine, $\mathrm{CZ}$ & INA bacterium & 2006 \\
\hline P. tolaasii & VURV-B 172 & grape wine, $\mathrm{CZ}$ & $\begin{array}{l}\text { saprophyt accompanying } \\
\text { c. a. of crown gall }\end{array}$ & 2006 \\
\hline P. fluorescens & VURV-B 195 & grape wine, $\mathrm{CZ}$ & INA bacterium $\left(-4.5^{\circ} \mathrm{C}\right)$ & 2007 \\
\hline P. marginalis & VURV-B 203 & apricot, $\mathrm{CZ}$ & dark brown lesion in stone & 2014 \\
\hline P. marginalis & VURV-B 204 & apricot, $\mathrm{CZ}$ & dark brown lesion in stone & 2014 \\
\hline P. fluorescens & VURV-B 231 & tomato, $\mathrm{CZ}$ & $\begin{array}{l}\text { saprophyt accompanying } \\
\text { different CA }\end{array}$ & 2005 \\
\hline P. fluorescens & VURV-B 232 & $\begin{array}{l}\text { Amaryllis, import } \\
\text { from NL }\end{array}$ & $\begin{array}{l}\text { saprophyt accompanying } \\
\text { CA of soft rot }\end{array}$ & 2005 \\
\hline P. fluorescens & VURV-B 233 & tomato, $\mathrm{CZ}$ & $\begin{array}{l}\text { saprophyt accompanying } \\
\text { different CA }\end{array}$ & 2005 \\
\hline
\end{tabular}

Table 1. List of phytopathogenic strains tested. Legend: $\mathrm{NL}$ - Netherlands, CZ - Czech Republic, CA - causal agent, INA - ice nucleation active strain, Year $_{\text {iso }}-$ Year of isolation. Strains susceptible to antimicrobial agents produced by Antarctic Pseudomonas spp. are in grey. 


\section{Antimicrobial activity detection}

The overlay spot plate assay (Micenková et al. 2014) was used for the detection of bacteriocin-like inhibition of phytopathogens by Antarctic Pseudomonas spp. The tested strains were inoculated on the TY agar supplemented with mitomycin $\mathrm{C}$ (final concentration $5 \mu \mathrm{g} / \mathrm{ml}$ ) and the plates were incubated at $4^{\circ} \mathrm{C}$ for 7 days in chamber refrigerator. Tested strain (potentially bacteriocin producer) was killed by chloroform vapors (30-min exposure) and overlayed with soft TY medium $(0.6 \%$ of agar; wt./vol.) containing $10^{8}$ cells of the phyto-

\section{Results and Discussion}

Altogether, 756 individual tests covering 36 producers and 21 indicator strains were performed (in two replications). A total of 4 strains, namely $P$. prosekii CCM 8878, CCM 8879, and CCM 8881 and Pseudomonas sp. CCM 8880, exhibited antagonistic activity against plant-pathogenic Pseudomonas spp., see Fig. 1.

Pseudomonas prosekii CCM 8879 and CCM 8881 were able to inhibit 4 strains of P. viridiflava (VURV-B 069, 070, 071, and 169) which caused soft rot symptoms. $P$. viridiflava is a multihost phytopathogen infecting important agricultural crops, e.g. tomato (Solanum lycopersicum), melon (Cucumis melo) or eggplant (Solanum melongena). Production of pectinolytic enzymes might be pointed out as an underlying biochemical mechanism since it leads to soft rot symptoms and stem necrosis (Goumans and Chatzaki 1998, Sarris et al. 2012). All inhibition zones were wide (ranging from 4 to $20 \mathrm{~mm}$ ), with the blurry edges so based on this observation, on inducibility by mitomoycin $\mathrm{C}$ and on presence of pyocin genes in the genomes of the producers, we speculate that inhibition was mediated by soluble pyocins. In both genomes, gene for L-type pyocin was detected, and an additional gene for pathogen culture. The plates were subsequently cultivated at $30^{\circ} \mathrm{C}$ for $24 \mathrm{~h}$. All combination of potential producers and phytopathogens were assessed. All samples were independently tested in replicates of two.

Identification of tailocins (R-, F-type pyocins) and/or soluble pyocins (S-type, L-type, M-type or microcin) were based on whether a small zone (1-2 $\mathrm{mm}$, typical for tailocins) or large diffuse zone ( $>3 \mathrm{~mm}$, soluble pyocin production) was observed (Fyfe et al. 1984, Grinter et al. 2012).

S9-type pyocin was found in the strain CCM 8881 (Snopková et al. 2021). Based on similar inhibition spectra, we suggest that the observed antagonisms towards $P$. viridiflava were caused by L-type pyocins. Both pyocin types (L and S9) are relatively rare among Pseudomonas spp.; with occurrence lower than $5 \%$ of nonaeruginosa pseudomonads (Ghequire and De Mot 2014). Harboring of L-pyocin genes is significantly associated with soildwelling or plant-associated isolates (Ghequire et al. 2018, Grinter et al. 2012, Parret et al. 2005). Genes encoding L-pyocin could be harbored as a cargo gene in tailocin or prophage clusters and therefore horizontally disseminated (Ghequire et al. 2015). On the other hand, S9 pyocins were predicted in silico in several Pseudomonas spp., mainly in the $P$. fluorescens clade (Ghequire and De Mot 2014). Sharp et al. (2017) speculated that pyocin S9 forms a separate group beside other pyocins. The C-terminal domain of S9 pyocins has an $\mathrm{HNH}$ motif and DNase activity similar domains of pyocins S1 or S2 whereas the N-terminal domain is disordered and exhibit great variability in size and amino acid composition (Ghequire and De Mot 2014). 


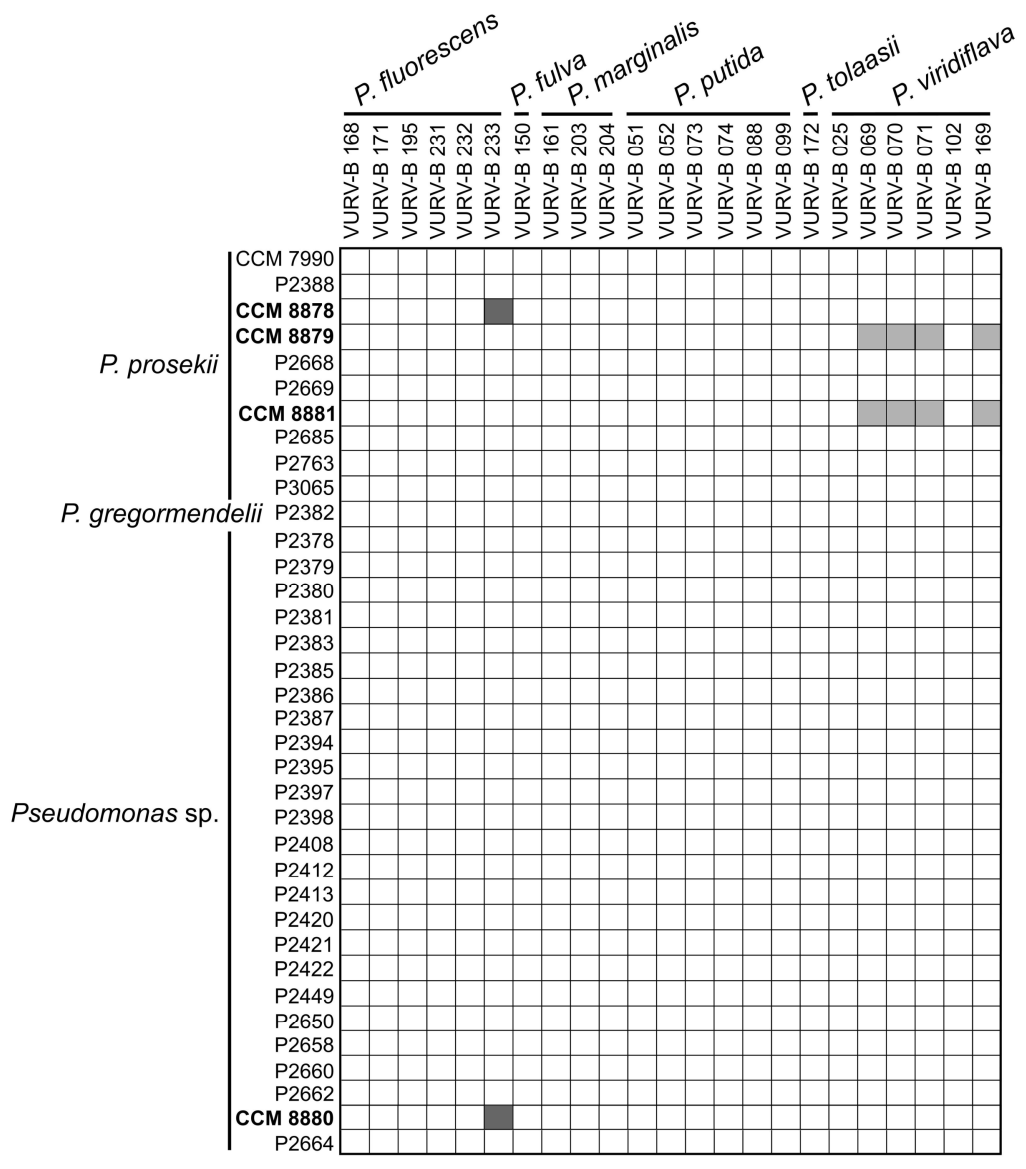

Fig. 1. Inhibitory activity of Antarctic Pseudomonas on phytopathogenic strains. Each row represents the inhibitory activity of Antarctic Pseudomonas strain (i.e., potential producer), and each column shows susceptibility of the phytopathogenic strain (i.e., indicator). Light grey boxes indicate inhibition interaction mediated by soluble antimicrobials, dark grey boxes by particle antimicrobials. Antimicrobial producers are shown in bold.

Strains CCM 8878 and CCM 8880 inhibited only one of the 21 tested strains, P. fluorescens CPPB-233. P. fluorescens encompasses mainly saprophytes and rootassociated strains, less frequently plant pathogens (Schroth et al. 2006). Further, many strains belong to the Plant Growth Promoting Rhizobacteria (PGPR) enhancing plant growth and reduce severity of various diseases (Ganeshan and Manoj Kumar 2005). Both inhibition zones were narrow (about $1 \mathrm{~mm}$ ) which can be attrib- uted to HMW pyocin (tailocin) production. Tailocins were detected in both strains in the previous study using electron micrographs (see Fig. 2). Gene mining analysis revealed corresponding gene clusters (Snopková et al. 2021). Strain CCM 8880 contained also a gene for soluble pyocin from S9 group but character of the inhibition zone corresponded rather to the high-molecular pyocin production. Based on the classification developed by Ghequire et al. (2015), the R-type tailocin pro- 
duced by CCM 8878 belongs to the Rp3 group (with homology to Vibrio parahaemolyticus VP882 phage and Halomonas aquamarina phage HAP-1). The Rtailocin of CCM 8880 belongs to the Rp4 group (with homology to Mu-like "Shigella flexneri" phage). Both clusters were located in a hot spot mutS-cinA, and both contain also few cargo genes, mainly tox- ins (Snopková et al. 2021). Recent studies focused on bacterial interactions suggest that tailocin production could be an important factor shaping plant or soil microbiome resulting in reduction of species diversity (Dorosky et al. 2017, Ghequire et al. 2015, Hockett et al. 2015), but no study on interaction among phytopathogens has been performed.

\section{CCM 8878 CCM 8880}
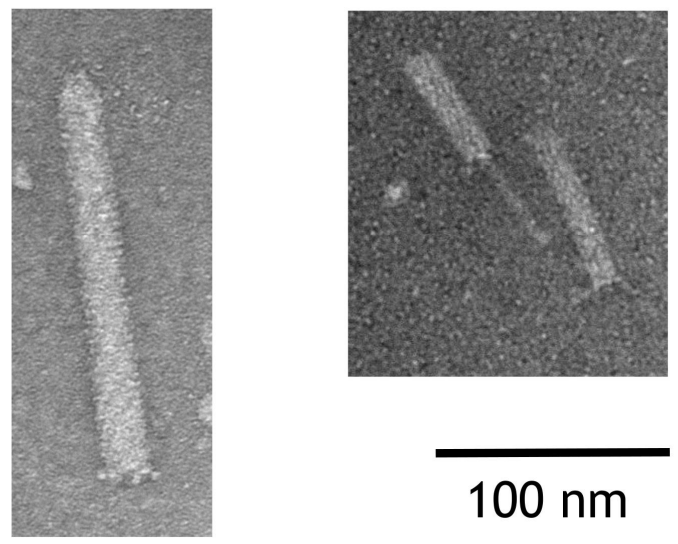

Fig. 2. Tailocin produced by $P$. prosekii CCM 8878 and Pseudomonas spp. CCM 8880. Electron micrographs adopted from Snopkova et al. 2021 (study contained detailed methodology for TEM). Scale bar represents $100 \mathrm{~nm}$.

Phytopathogens are annually responsible for considerable losses due to the disease and spoilage of crops (Strange and Scott 2005). Commercially used metalbased bactericides have been applied in agriculture to control plant pathogenic bacteria, but these compounds bring several disadvantages, such as e.g.; phytotoxicity, non-specificity, and risk of resistance development. Pristine Antarctic environment could be a source of new antimicrobials equipped by activity at low temperature. Several studies have shown that bacteriocins are effective against phytopathogenic bacteria; tailocin produced by $P$. fluorescens SF4c antagonizes several phytopatho- genic Pseudomonas spp. and Xanthomonas spp. (Fernandez et al. 2017, Príncipe et al. 2018). Putidacin L1 (producer strain P. putida BW11M1) exhibited cytotoxic activity against number of phytopathogenic pseudomonad species (Parret et al. 2003), and bacteriocin (producer $P$. syringae pv. ciccaronei) might be used in the prevention of olive knot disease (Lavermicocca et al. 2002). Nevertheless, the use of bacteriocins as biocontrol agents in plants is yet limited due to our insufficient knowledge about bacteriocin inhibition spectra, inhibition kinetics and their other interaction with plant-associated microbiome which request further research. 
ANTARCTIC PSEUDOMONADS ANTAGONIZE PHYTOPATHOGENIC SPECIES

\section{Conclusion}

Our study confirmed a high potential of Antarctic pseudomonads in control of economically important plant disease. Three out of four inhibition interactions were mediated by recently described Antarctic species $P$. prosekii producing L-type pyocin or tailocin.

\section{References}

Barreteau, H., Tiouajni, M., Graille, M., Josseaume, N., Bouhss, A., Patin, D., Blanot, D., Fourgeaud, M., Mainardi, J.-L., Arthur, M., van Tilbeurgh, H., Mengin-LecreulX, D. and TouzÉ, T. (2012): Functional and structural characterization of PaeM, a colicin M-like bacteriocin produced by Pseudomonas aeruginosa. The Journal of Biological Chemistry, 287(44): 37395-37405.

Dorosky, R. J., Yu, J. M., Pierson, L. S. and Pierson, E. A. (2017): Pseudomonas chlororaphis produces two distinct R-tailocins that contribute to bacterial competition in biofilms and on roots. Applied and Environmental Microbiology, 83(15).

Fernandez, M., Godino, A., Príncipe, A., Morales, G. M. and Fischer, S. (2017): Effect of a Pseudomonas fluorescens tailocin against phytopathogenic Xanthomonas observed by atomic force microscopy. Journal of Biotechnology, 256: 13-20.

Flury, P., Aellen, N., Ruffner, B., Péchy-Tarr, M., Fataar, S., Metla, Z., DominguezFerreras, A., Bloemberg, G., Frey, J., Goesmann, A., RaAijmakers, J. M., Duffy, B., Höfte, M., Blom, J., Smits, T. H. M., Keel, C. and Maurhofer, M. (2016): Insect pathogenicity in plant-beneficial pseudomonads: Phylogenetic distribution and comparative genomics. The ISME Journal, 10(10): 2527-2542.

Fyfe, J. A., HarRis, G. and Govan, J. R. (1984): Revised pyocin typing method for Pseudomonas aeruginosa. Journal of Clinical Microbiology, 20(1): 47-50.

Ganeshan, G., Manoj Kumar, A. (2005): Pseudomonas fluorescens, a potential bacterial antagonist to control plant diseases. Journal of Plant Interactions, 1(3): 123-134.

GHEQUIRE, M. G. K., DE Mot, R. (2014): Ribosomally encoded antibacterial proteins and peptides from Pseudomonas. FEMS Microbiology Reviews, 38(4): 523-568.

Ghequire, M. G. K., Dillen, Y., Lambrichts, I., Proost, P., Wattiez, R. and De Mot, R. (2015): Different ancestries of R tailocins in rhizospheric Pseudomonas isolates. Genome Biology and Evolution, 7(10): 2810-2828.

GHequire, M. G. K., ÖztÜrk, B. and De Mot, R. (2018): Lectin-like bacteriocins. Frontiers in Microbiology, 9: 2706.

Goumans, D. E., Chatzaki, A. K. (1998): Characterization and host range evaluation of Pseudomonas viridiflava from melon, blite, tomato, chrysanthemum and eggplant. European Journal of Plant Pathology, 104(2): 181-188.

Grinter, R., Milner, J. and Walker, D. (2012): Bacteriocins active against plant pathogenic bacteria. Biochemical Society Transactions, 40(6): 1498-1502.

Hockett, K. L., Renner, T. and Baltrus, D. A. (2015): Independent co-option of a tailed bacteriophage into a killing complex in Pseudomonas. mBio, 6(4): e00452.

Hu, J., Yang, T., Friman, V. P., Kowalchuk, G. A., Hautier, Y., Li, M., Wei, Z., Xu, Y., Shen, Q. and JousSET, A. (2021): Introduction of probiotic bacterial consortia promotes plant growth via impacts on the resident rhizosphere microbiome. Proceedings. Biological sciences, 288 (1960): 20211396.

Lavermicocca, P., Lonigro, S. L., Valerio, F., Evidente, A. and Visconti, A. (2002): Reduction of olive knot disease by a bacteriocin from Pseudomonas syringae pv. Ciccaronei. Applied and Environmental Microbiology, 68(3): 1403-1407.

Loper, J. E., Hassan, K. A., Mavrodi, D. V., Davis, E. W., Lim, C. K., Shaffer, B. T., Elbourne, L. D. H., Stockwell, V. O., Hartney, S. L., Breakwell, K., Henkels, M. D., Tetu, S. G., Rangel, L. I., Kidarsa, T. A., Wilson, N. L., van de Mortel, J. E., Song, C., Blumhagen, 
R., Radune, D. and Paulsen, I. T. (2012): Comparative genomics of plant-associated Pseudomonas spp.: Insights into diversity and inheritance of traits involved in multitrophic interactions. PLoS Genetics, 8(7): e1002784.

Majeed, H., Gillor, O., Kerr, B. and Riley, M. A. (2011): Competitive interactions in Escherichia coli populations: The role of bacteriocins. The ISME Journal, 5(1): 71-81.

McCaughey, L. C., Grinter, R., Josts, I., Roszak, A. W., Waløen, K. I., Cogdell, R. J., Milner, J., Evans, T., Kelly, S., Tucker, N. P., Byron, O., Smith, B. and Walker, D. (2014): Lectin-like bacteriocins from Pseudomonas spp. Utilise D-rhamnose containing lipopolysaccharide as a cellular receptor. PLoS Pathogens, 10(2): e1003898.

Metelev, M., Serebryakova, M., Ghilarov, D., Zhao, Y. and Severinov, K. (2013): Structure of microcin B-like compounds produced by Pseudomonas syringae and species specificity of their antibacterial action. Journal of Bacteriology, 195(18): 4129-4137.

MicenkovÁ, L., Štaudová, B., BosÁK, J., Mikalová, L., LitTnerová, S., Vrba, M., ŠEvČííová, A., WozNicovÁ, V. and ŠMAJS, D. (2014): Bacteriocin-encoding genes and ExPEC virulence determinants are associated in human fecal Escherichia coli strains. BMCMicrobiology, 14: 109.

Michel-Briand, Y., BAYSSE, C. (2002): The pyocins of Pseudomonas aeruginosa. Biochimie, 84(5-6): 499-510.

Nakayama, K., Takashima, K., Ishihara, H., Shinomiya, T., Kageyama, M., Kanaya, S., Ohnishi, M., Murata, T., Mori, H. and Hayashi, T. (2000): The R-type pyocin of Pseudomonas aeruginosa is related to P2 phage, and the F-type is related to lambda phage. Molecular Microbiology, 38(2): 213-231.

Oluyombo, O., Penfold, C. and Diggle, S. (2019): Competition in biofilms between cystic fibrosis isolates of Pseudomonas aeruginosa is shaped by R-Pyocins. mBio, 10: e01828-18.

Palleroni, N. J. (2015): Genus I. Pseudomonas. In Garrity, G. M., Brenner, D. J., Krieg, N. R., Staley, J. T. (eds.): Bergey's manual of systematics of archaea and bacteria. Volume 2. Springer Verlag. New York. pp. 323-379.

Parret, A. H. A., Schoofs, G., Proost, P. and De Mot, R. (2003): Plant lectin-like bacteriocin from a rhizosphere-colonizing Pseudomonas isolate. Journal of Bacteriology, 185(3): 897-908.

Parret, A. H. A., Temmerman, K. and De Mot, R. (2005): Novel lectin-like bacteriocins of biocontrol strain Pseudomonas fluorescens Pf-5. Applied and Environmental Microbiology, 71(9): 5197-5207.

Passera, A., Compant, S., Casati, P., Maturo, M. G., Battelli, G., Quaglino, F., Antonielli, L., Salerno, D., Brasca, M., Toffolatti, S. L., Mantegazza, F., Delledonne, M. and MitTer, B. (2019): Not Just a Pathogen? Description of a plant-beneficial Pseudomonas syringae Strain. Frontiers in Microbiology, 10: 1409.

Príncipe, A., Fernandez, M., Torasso, M., Godino, A. and Fischer, S. (2018): Effectiveness of tailocins produced by Pseudomonas fluorescens SF4c in controlling the bacterial-spot disease in tomatoes caused by Xanthomonas vesicatoria. Microbiological Research, 212-213: 94-102.

Sarris, P. F., Trantas, E. A., Mpalantinaki, E., Ververidis, F. and Goumas, D. E. (2012): Pseudomonas viridiflava, a Multi Host Plant Pathogen with Significant Genetic Variation at the Molecular Level. PLoS ONE, 7(4): e36090.

Sharp, C., Bray, J., Housden, N. G., Maiden, M. C. J., Kleanthous, C. (2017): Diversity and distribution of nuclease bacteriocins in bacterial genomes revealed using Hidden Markov Models. PLOS Computational Biology, 13(7): e1005652.

Schroth, M., Hildebrand, D. and Panopoulos, N. (2006): Phytopathogenic Pseudomonads and Related Plant-Associated Pseudomonads. In: M. Dworkin, S. Falkow, E. Rosenberg, K. H. Schleifer, E. Stackebrandt (eds.): The Prokaryotes, Volume 6, $3^{\text {rd }}$ ed., Springer Verlag. New York. pp. 714-740.

Smith, I. M., Dunez, J., Phillips, D. H., Lelliott, R. A. and Archer, S. A. (eds.) (2009): European handbook of plant diseases. John Wiley \& Sons. pp. 136-175.

Snopková, K., Dufková, K., Chamrád, I., Lenobel, R., ČejKová, D., Kosina M., Hrala, M., HolÁ, V., SedláčeK, I. and Šmajs, D. (2021, Online ahead of print.): Pyocin-mediated antagonistic interactions in Pseudomonas spp. Isolated in James Ross Island, Antarctica. Environmental Microbiology. doi: 10.1111/1462-2920.15809 
SNOPKOVÁ, K., SEDLÁČEK, I. and ŠMAJS, D. (2018): First evidence of high-molecular-weight bacteriocin (tailocin) produced by Antarctic Pseudomonas spp. Czech Polar Reports, 8(2): 178185.

Strange, R. N., Scott, P. R. (2005): Plant disease: A threat to global food security. Annual Review of Phytopathology, 43: 83-116.

Terauds, A., LeE, J. R. (2016): Antarctic biogeography revisited: Updating the Antarctic Conservation Biogeographic Regions. Diversity and Distributions, 22(8): 836-840. 